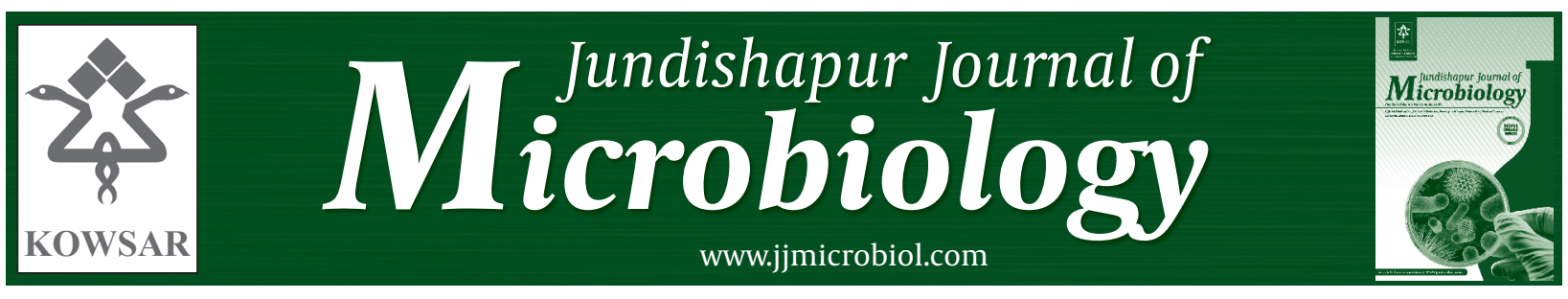

\title{
Seroprevalence of Measles, Mumps and Rubella Antibodies in 18 Months and 6.5 Years Old Children: Six Months After Measles-Mumps-Rubella (MMR) Vaccination
}

\author{
Ahmad Shamsizadeh ${ }^{1,2}$, Roya Nikfar ${ }^{2 *}$, Manoochehr Makvandi ${ }^{1}$, Mehran Hakimzadeh ${ }^{2}$, \\ Mohsen Alisamir ${ }^{2}$, Tahereh Ziaei ${ }^{2}$ \\ ${ }^{1}$ Jundishapur Infectious and Tropical Diseases Research Center, Ahvaz Jundishapur University of Medical Sciences, Ahvaz, IR Iran \\ ${ }^{2}$ Abuzar Children's Hospital, Ahvaz Jundishapur University of Medical Sciences, Ahvaz, IR Iran
}

\section{A R T I C L E I N F O}

Article type:

Original Article

\section{Article history:}

Received: 02 Feb 2012

Revised: 20 Feb 2012

Accepted: 22 Feb 2012

\section{Keywords:}

Measles

Mumps

Rubella

Seroepidemiologic Studies

\begin{abstract}
A B S T R A C T
Background: Mumps, measles and rubella viruses lead to various kinds of complications such as meningoencephalitis, deafness, congenital abnormalities and even cause mortality in malnourished patients,. Since 2004, MMR vaccination in two series of one year of age and four to six years has been administered to Iranian children as a part of routine vaccination program. Recently, MMR vaccination schedule has been changed to one year and 18 months series.

objectives: Since MMR vaccine has been recently entered childhood vaccination program, this study was performed to determine immunity response against mumps, measles and rubella six months after one year and four to six years of age vaccination.

Patients and Methods: In a cross-sectional study, antibody titers after MMR vaccination at 18 months (six months after dose of one year) in 70 children, and at 6.5 years (six month after dose of six years) in 90 children referred to Ahvaz Abuzar Children's Hospital Vaccination Clinic during 2007-2008 were detected by ELISA method.

Results: In 70 children (34 boys and 36 girls) who were vaccinated at one year, 30 (42.9\%) had antibody against measles, 63 (90\%) against rubella and 41 (58.6\%) against mumps. In 90 children ( 54 boys and 36 girls at 6.5 years of age (six months after vaccination), 41 (45.6\%) children had antibody against measles, 79 (87.8\%) against rubella and 69 (76.7\%) against mumps.

Conclusions: the results of this study showed that after MMR vaccination, the level of antibody for measles was about $45 \%$ and for mumps about 50-80 \%. This level of immunity is not acceptable for successful vaccination. while the level of antibody against rubella was sufficient. For better evaluation of MMR vaccination, further studies and from other parts of the country is needed.
\end{abstract}

Published by Kowsar Corp, 2012. cc 3.0.

- Implication for health policy/practice/research/medical education:

This study determined the level of immunity after MMR vaccination in 18 months and 6 years old children.

Please cite this paper as:

Shamsizadeh A, Nikfar R, Makvandi M, Hakimzadeh M, Alisamir M, Ziaei T. Seroprevalence of Measles, Mumps and Rubella Antibodies in 18 Months and 6.5 Years Old Children: Six Months After Measles-Mumps-Rubella (MMR) Vaccination. Jundishapur J Microbiol. 2012;5(4): 578-81. DOI: $10.5812 / j j m .4563$.

${ }^{*}$ Corresponding author: Roya Nikfar, Abuzar children's Hospital, Ahvaz Jundishapur University of Medical Sciences, Ahvaz, IR Iran. Tel: +98-9121598404, Fax: +986114444711, E-mail: nikfarroya@yahoo.com

DOI: $10.5812 / j \mathrm{jm} .4563$

(C) 2012 Ahvaz Jundishapur University of Medical Sciences; Published by Kowsar Corp.

This is an Open Access article distributed under the terms of the Creative Commons Attribution License (http://creativecommons.org/licenses/by/3.0), which permits unrestricted use, distribution, and reproduction in any medium, provided the original work is properly cited. 


\section{Background}

Measles, mumps and rubella are acute viral infectious diseases of childhood with high mortality and morbidity especially in malnourished children. The importance of these diseases is not only due to their ability to spread rapidly and leave high number of cases, but also to the severity of their complications (1). Measles is a highly contagious disease with several complications such as otitis media, pneumonia and encephalitis. Mumps is also an acute communicable disease can cause meningoencephalitis in children and epididymo-orchitis in adolescent boys (2). Rubella is a generally mild, exanthematous illness with low morbidity and mortality in children, however, infection in pregnancy may result fetal involvement and congenital rubella syndrome (3). Because, these viral illnesses do not have any specific treatment, the best way for prevention is vaccination.

Measles, mumps and Rubella (MMR) vaccine has been included as a part of immunization program in developed countries since the 1970s (4). In Iran, measles vaccination in ages of nine and 15 months was a part of routine ammunition of children up to 2004 (5), and after this year vaccination by MMR vaccine was substituted and all of children were vaccinated at 12 months and four to six years of age (6). In 2008, MMR vaccination schedule changed to 12 and 18 months of age by this vaccine (7). In Iran, MMR vaccine is a relatively new vaccine and information about efficacy of this vaccine is low. Time by time evaluation of efficacy of vaccines is a useful method to plan further vaccination schedule and eradication of communicable diseases. Therefore, we decided to assess the antibody level to measles, mumps and rubella six months after MMR vaccination in children who received the vaccine at 12 months and six years of age.

\section{Objectives}

The aim of this study was to assess antibody response to measles, mumps and rubella in 18 months and 6.5 years old children, six months after MMR vaccination.

\section{Patients and Methods}

In a cross-sectional study, blood samples were obtained from children who referred to vaccination clinic of Abuzar Children's Hospital (the main children hospital of Ahvaz). The study population consisted of two age groups. The first were 18 months old children who received a dose of MMR (Razi Institute of Iran) vaccine six months ago and the second group were 6.5 years old who were vaccinated by MMR vaccine at the age of six. This group of children had received measles vaccine at nine and 15 months of age according to past vaccination program. Before sampling, all children were examined by a physician and if there was not any evidence of immunosuppression (malignancy, immunodeficiency, radiotherapy, use of corticosteroids or other immunosuppressant drugs), entered the study.

After parental consent was taken, $3 \mathrm{ml}$ of blood was collected from each child. Sera were separated and stored at $-70^{\circ} \mathrm{C}$ in Virology Laboratory of Ahvaz Medical School for about three months. At the end of sampling, IgG antibodies to mumps, measles and rubella were detected by enzyme-linked immunosorbent assay (ELISA) method using commercial ELISA kit (RADIM diagnostics, Italy) according to its manufacturer's instructions. Statistical analysis was carried out using SPSS software version 13. Chi-square test was used for the statistical evaluation of the results obtained in the study.

\section{Results}

The study included 70 cases of 18 months of age and 90 cases of 6.5 years of age. In 18 months of age group, 34 (48.6\%) were males and 36 (51.4\%) females. Table 1 shows the results of antibodies against measles, mumps and rubella in 18 months old children. There was not any significant statistical difference in the seroprevalence of measles, mumps and rubella between males and females in this age group $(P>0.05)$. In 6.5 years old group, 54 (60\%) were males and 36 (40\%) females. Table 2 shows antibodies against measles, mumps and rubella in 6.5 years old

\begin{tabular}{ll|lll|ll|}
\hline \multicolumn{3}{l}{ Table 1. Antibodies Against Measles, Mumps and Rubella in 18 Months Old Children } \\
\hline & \multicolumn{5}{c}{ Mumps } & \multicolumn{3}{l}{ Rubella } \\
\hline Measles & Positive, No. (\%) & Negative, No. (\%) & Positive, No. (\%) & Negative, No. (\%) & Positive, No. (\%) & Negative, No. (\%) \\
\hline Female & $15(41.6)$ & $21(48.4)$ & $19(52.8)$ & $17(47.2)$ & $31(86)$ & $5(4)$ \\
Male & $15(44.1)$ & $19(55.9)$ & $22(64.7)$ & $12(35.3)$ & $32(94.1)$ & $2(5.9)$ \\
Total & $30(42.9)$ & $40(57.1)$ & $41(58.6)$ & $29(41.4)$ & $63(90)$ & $7(10)$ \\
\hline
\end{tabular}

\begin{tabular}{|c|c|c|c|c|c|c|}
\hline & \multicolumn{2}{|l|}{ Measles } & \multicolumn{2}{|l|}{ Mumps } & \multicolumn{2}{|l|}{ Rubella } \\
\hline & Positive, No.(\%) & Negative, No.(\%) & Positive, No.(\%) & Negative, No.(\%) & Positive, No.(\%) & Negative, No.(\%) \\
\hline Female & $17(47.2)$ & $19(52.8)$ & $29(80.5)$ & $7(19.5)$ & $35(97.2)$ & $1(2.7)$ \\
\hline Male & $24(44.4)$ & $30(55.6)$ & $40(74.1)$ & $14(25.9)$ & $44(81.4)$ & $10(18.6)$ \\
\hline Total & $41(45.6)$ & $49(54.4)$ & $69(76.7)$ & $21(23.3)$ & $79(87.8)$ & $11(12.2)$ \\
\hline
\end{tabular}


children. The prevalence of antibodies against measles and mumps in males and females was not statistically different $(P>0.05)$, but the level of rubella antibody in females and males was statistically different $(P=0.04)$ and female had better antibody response to rubella after MMR vaccination.

\section{Discussion}

The results of this study showed relatively high, moderate and poor response to rubella, mumps and measles component of MMR vaccine respectively, six months after vaccination of 12 months and six years old children. Six years old children had a better antibody response to MMR vaccine in comparison to 18 months old children. The prevalence of antibodies to measles, mumps and rubella after MMR vaccination were determined by many studies worldwide. The antibody response to rubella after MMR vaccination was more than $90 \%$ in most studies as our study showed (8-12).

For mumps, the antibody response ranged from 72 to $99.5 \%(4,11,13-18)$. In our study, the prevalence of mumps antibody after vaccination in 6.5 years old children was in this range but the percent of immune children to mumps in 18 months old children was lower than what was expected. Only the result of one study from Saudi Arabia was similar to our study (19). The seroprevalence of measles antibodies in our study in both groups were lower than other studies worldwide $(1,4,12,15,20,21)$.

he antibody response after MMR vaccination to measles in 18 months of age group was about $43 \%$ and in 6.5 years of age was about $46 \%$. It is notified that all 6.5 years old children have received two doses of measles vaccine in infancy and a dose of MMR in six years old. Because MMR is a new vaccine, the studies about effectiveness of this vaccine in Iran is limited, whereas most studies evaluated the seroprevalence of measles antibody after measles vaccination (22). We do not have any explanations for statistical difference in seropositivity between males and females in 6.5 years old children. Other studies have not shown any significant difference between genders (23, 24).

ince, historically measles have been a common disease in Iran and according to the world health organization (WHO) schedules, Iran is in the elimination stage of measles (25), so this low rate of seropositiveness after MMR vaccination is not acceptable. Recently some Health officials have reported some measles outbreaks in southern states of the country (26). Some reasons which are considered as the causes of low effectiveness of vaccines, include; type of the vaccine, lack of cold chain preservation of vaccine and poor technique in administration of vaccine. Anyway whatever the reason of poor vaccine response is, this level of seropositiveness after MMR vaccination at least in our region is unacceptable.
One limitation of our study was, we did not check antibody level before vaccination and some children might be seropositive before vaccination. The other problem was changing of the country vaccination schedule during the study period. Our suggestion is to evaluate antibody response to MMR vaccine before and after vaccination, and in a large vaccine population. Our study revealed a good response for rubella, a moderate response for mumps and a poor response for measles after MMR vaccination. Whereas, at the present time, Iran is in the measles eradication phase, this low level of protection against measles is worrisome. Since, besides of the results of this study, some reports indicate outbreaks of measles in some areas of the country, further studies are needed to evaluate antibody response to measles, mumps and rubella after MMR vaccination in other parts of the country.

\section{Acknowledgments}

This paper is a product of thesis project for specialty of pediatrics. We thank all the participant children and their families, whose participation allowed to conduct the study. We also thank Mrs. Shohreh Nabidavoodi for preparation the manuscript.

\section{Financial disclosure}

The authors declare no financial disclosure.

\section{Funding/Support}

Funding for this work was provided by Ahvaz Jundishapur University of Medical Sciences (Grant No. U-86120).

\section{References}

1. Gabutti G, Rota MC, Salmaso S, Bruzzone BM, Bella A, Crovari P. Epidemiology of measles, mumps and rubella in Italy. Epidemiol Infect. 2002;129 (3):543-50.

2. Litman N, Baum S. Mumps virus. In: Mandel G, Bennett J, Dolin R, editors. Douglas and Bennett's Principles and Practice of Infectious Diseases. Philadelphia: Elsevier Churchil Livingstone; 2010. p. 2201-6.

3. Cherry J. Rubella virus. In: Feigin R, JD. C, Denmler-Harrison G, Kaplan S, editors. Feigin \& cherry's Textbook of pediatric Infectious Diseases. Philadelphia Saunders; 2009. p. 2271-300.

4. Yadav S, Thukral R, Chakarvarti A. Comparative evaluation of measles, mumps \& rubella vaccine at $9 \& 15$ months of age. Indian JMed Res. 2003;118:183-6.

5. Iran MoHotIRo. Schedule and guideline of immunization. Tehran: Ministry of Health Publication; 1999.

6. Iran MoHotIRo. Schedule and guideline of immunization. Tehran: Ministry of Health Publications; 2005.

7. Iran MohotIRo. Schedule and guideline of immunization. Tehran: Ministry of Health Publications; 2009.

8. Halperin SA, Ferrera G, Scheifele D, Predy G, Stella G, Cuccia M, et al. Safety and immunogenicity of a measles-mumps-rubella-varicella vaccine given as a second dose in children up to six years of age. Vaccine. 2009;27 (20):2701-6.

9. Raut SK, Kulkarni PS, Phadke MA, Jadhav SS, Kapre SV, Dhere RM et al. Persistence of antibodies induced by measles-mumps-rubella vaccine in children in India. Clin Vaccine Immunol. 2007;14 (10):1370-1.

10. Redd SC, King GE, Heath JL, Forghani B, Bellini WJ, Markowitz LE. Comparison of vaccination with measles-mumps-rubella vac- 
cine at 9, 12, and 15 months of age. J Infect Dis. 2004;189 Suppl 1:S116-22.

11. Vesikari T, Baer M, Willems P. Immunogenicity and safety of a second dose of measles-mumps-rubella-varicella vaccine in healthy children aged 5 to 6 years. Pediatr Infect Dis J. 2007;26 (2):153-8.

12. Yalcin SS, Kanra G, Pehlivan T. Outbreak of measles in medical students and determination of immune status to measles-mumpsrubella viruses. Int J Adolesc Med Health. 2006;18 (4):615-22.

13. Dominguez A, Torner N, Castilla J, Batalla J, Godoy P, Guevara M, et al. Mumps vaccine effectiveness in highly immunized populations. Vaccine. 2010;28 (20):3567-70.

14. Fylaktou A, Haidopoulou K, Goutaki M, Papadimitriou E, Kalamitsiou S, Papaventsis D. Measles and mumps immunity in Northern Greece, 2004-2007. Euro Surveill. 2008;13 (16).

15. Mossong J, Putz L, Schneider F. Seroprevalence of measles, mumps and rubella antibodies in Luxembourg: results from a national cross-sectional study. Epidemiol Infect. 2004;132 (1):11-8.

16. Pebody RG, Gay NJ, Hesketh LM, Vyse A, Morgan-Capner P, Brown DW, et al. Immunogenicity of second dose measles-mumps-rubella (MMR) vaccine and implications for serosurveillance. Vaccine. 2002;20 (7-8):1134-40.

17. Schuster V, Otto W, Maurer L, Tcherepnine P, Pfletschinger U, Kindler $\mathrm{K}$, et al. Immunogenicity and safety assessments after one and two doses of a refrigerator-stable tetravalent measlesmumps-rubella-varicella vaccine in healthy children during the second year of life. Pediatr Infect Dis J. 2008;27 (8):724-30.

18. Tharmaphornpilas $\mathrm{P}$, Yoocharean P, Rasdjarmrearnsook AO, Theamboonlers A, Poovorawan Y. Seroprevalence of antibodies to measles, mumps, and rubella among Thai population: evalu- ation of measles/MMR immunization programme. J Health Popul Nutr. 2009;27 (1):80-6.

19. Jaber SM. A serological survey of measles, mumps and rubella immunity among school aged children in Western Saudi Arabia. Saudi Med J. 2006;27 (1):63.

20. Johnson CE, Kumar ML, Whitwell JK, Staehle BO, Rome LP, Dinakar C, et al. Antibody persistence after primary measles-mumpsrubella vaccine and response to a second dose given at four to six vs. eleven to thirteen years. Pediatr Infect Dis J.1996;15 (8):687-92.

21. Miller E, Hill A, Morgan-Capner P, Forsey T, Rush M. Antibodies to measles, mumps and rubella in UK children 4 years after vaccination with different MMR vaccines. Vaccine. 1995;13 (9):799-802.

22. Loo MK, Sabahi F, Soleimanjdahi H, Kazemnejad A, Roustai MH. Seroprevalence of neutralizing antibodies to measles virus in a vaccinated population in Iran, 1998. Eur J Epidemiol. 2003;18 (11):1085-9.

23. Gurgoze MK, Yilmaz E, Godekmerdan A, Akca Z, Dogan Y, Akarsu $\mathrm{S}$, et al. Seroprevalence of mumps, varicella and rubella antibodies in children 1-16 years of age in eastern Turkey. Turk J Pediatr. 2006;48 (3):185-8.

24. Muhsen K, Aboudy Y, Mendelson E, Green MS, Cohen D. Prevalence of mumps antibodies in the Israeli population in relation to mumps vaccination policy and incidence of disease. Epidemiol Infect. 2008;136 (5):688-93.

25. Gaafar T, Moshni E, Lievano F. The challenge of achieving measles elimination in the eastern Mediterranean region by 2010.J Infect Dis. 2003;187 Suppl 1:S164-71.

26. Izadi S, Zahraei SM, Sartipi M. An investigation into a measles outbreak in southeast Iran.Jpn J Infect Dis. 2012;65 (1):45-51. 